\title{
PNEUMOPERITÔNEO E PNEUMORETROPERITÔNEO COMO INDICATIVOS DE RUPTURA DE VÍSCERAS OCAS EM UM CÃO E UM GATO
}

(Pneumoperitoneum and pneumoretroperitoneum as an indicative of hollow viscera rupture in a dog and a cat)

Marina Silvestre Sombrio, Danielle Buch, Alana Anselmo, Thais Alves, Tilde Froes

Universidade Federal do Paraná, Curitiba, Paraná, Brasil.

*Correspondência: marinasiso@hotmail.com

RESUMO: Pneumoperitôneo é definido como gás livre na cavidade peritoneal e pode ser resultado de trauma penetrante ou cirurgia abdominal. Em cães e gatos, a infecção abdominal por organismos produtores de gás, extravasamento de gás por ruptura de vísceras ocas e migração de gás decorrente da distensão de parede das vísceras são outros diferenciais (Smelstoys et al., 2004). Este relato descreve os aspectos radiográficos da ruptura não traumática de cólon em um cão e um gato, acarretando o pneumoretroperitôneo e pneumoperitôneo. Foram atendidos um cão macho, de quatro anos, e uma gata, de três anos, ambos sem raça definida. O cão apresentava aumento de volume em região perineal há 14 dias, tinha vômitos frequentes e aquesia há quatro dias. Na palpação retal, notou-se uma hérnia perineal e fecaloma. Já a gata apresentava um aumento abdominal progressivo e apatia, e suspeitou-se de gestação. A radiografia abdominal dos pacientes revelou distensão abdominal, presença de coleção fluida peritoneal ventral e acúmulo de gás livre promovendo o maior detalhamento das estruturas abdominais e retroperitoneais caracterizando pneumoperitôneo e pneumoretroperitôneo. O conjunto de achados radiográficos foi sugestivo de ruptura de vísceras ocas. No cão, a hérnia perineal envolvia a porção final do cólon descendente e formou uma saculação retal, a qual promoveu dilatação dos segmentos craniais e fecaloma. No gato, já se indicou a laparotomia exploratória com os achados do exame simples. Porém no cão, após a abdominocentese, injetou-se contraste iodado não iônico por via retal para tentar se determinar o ponto da ruptura, mas se observou apenas o extravasamento do contraste na cavidade. Em ambos pacientes, a ruptura de cólon descendente foi confirmada pela enterectomia. Assim como descrito por Saunders e Tobias (2003), ambos os presentes casos de pneumoperitônio foram classificados como não traumáticos. Embora seja relatado que o pneumoperitôneo seja frequentemente resultado de cirurgia abdominal ou trauma penetrante (Smelstoys et al., 2004), este relato aborda a ocorrência de pneumoperitôneo e pneumoretroperitôneo devido ao extravasamento de gás por ruptura de vísceras ocas, secundário a uma possível obstrução intestinal no cão (hérnia perineal e fecaloma), e de causa indeterminada no gato. Os animais do presente estudo eram adultos jovens, diferente do que cita Saunders e Tobias (2003) sobre a prevalência maior de pneumoperitônio em animais idosos. E nestes casos não havia histórico de neoplasia ou da administração de antinflamatórios esteroides e não esteroides provocando ulcerações, como possível causa da ruptura do trato gastrointestinal. Resultados radiográficos falsos negativos na pesquisa de ruptura de vísceras ocas podem ocorrer quando há mínima quantidade de ar livre na cavidade, principalmente na suspeita de úlceras rompidas. Quando o pneumoperitôneo e pneumoretroperitôneo são identificados pelo exame radiográfico são fortemente indicativos de ruptura do trato gastrintestinal, apesar da não determinação do ponto exato da ruptura. Infere-se que a identificação do pneumoperitôneo e pneumoretroperitôneo pelo exame radiográfico abdominal em cães e gatos, sem histórico de cirurgia abdominal prévia, deve ser considerada uma emergência, sendo indicada a laparotomia exploratória, e que o pneumoretroperitônio pode estar causado pela ruptura do cólon, a exemplo dos pacientes neste relato.

Palavras-chave: canino; diagnóstico por imagem; felino; radiografia abdominal; ruptura de cólon. 


\section{Referências}

SAUNDERS, W. B.; TOBIAS, K. M. Pneumoperitoneum in dogs and cats: 39 cases (19832002). Journal of the American Veterinary Medical Association, v. 223, n. 4, p. 462-468, 2003.

SMELSTOYS, J. A. et al. Outcome of and prognostic indicators for dogs and cats with pneumoperitoneum and no history of penetrating trauma: 54 cases (1988-2002). Journal of the American Veterinary Medical Association, v. 225, n. 2, p. 251-255, 2004. 